\title{
Justice with mercy: About a contemporary Palestinian theology
}

\author{
Knud Jeppesen ${ }^{1}$ \\ Tantur Ecumenical Institute for Theological Studies (Jerusalem) \\ Research Associate: Faculty of Theology \\ University of Pretoria
}

\begin{abstract}
Arab Christianity has a long history, longer than the history Christianity has in many European countries, a fact we seem to have forgotten in the west. According to Acts 2:11, some Arabs together with several other people of different nationalities were present when Peter gave his address to the crowd on the first Pentecost day after the ascension of Christ. Even if this piece of information is not historically true, there is no doubt that Christianity spread to the Arab world fairly early, probably in the beginning with some JudaeoChristians, who moved to Arabia, and later on as a result of a mission to the gentiles. Already in antiquity the Bible was translated from the Greek Septuagint into Arabic.
\end{abstract}

\section{THE MADEBA MAP}

One of the archaeological findings, which shows the extension of Christianity in part of what we today call the Arab world, is the famous map in the orthodox St George's church in Madeba in Jordan (Piccirillo 1997:26-34, 8195). The map is a mosaic probably made around $560 \mathrm{CE}$. Today you cannot see the original map in full, but from what is left, it is clear, that it at least has shown the area from Tyre and Sidon in the north to the Nile delta in the south and from the Mediterranean Sea in the west to the desert in the east.

The place names on the map are written in Greek and designate towns and holy places known from the Bible and early Christian sources. Several Christian sanctuaries are mentioned, to which pilgrims went according to contemporary Christian literature. The map is therefore rightly understood as a pilgrims' map, which reflect the extension and importance of Christianity in

\footnotetext{
${ }^{1}$ Dr Knud Jeppesen, Vice Rector Emeritus, Tantur Ecumenical Institute for Theological Studies (Jerusalem, Israel), is a member of the International Advisory Board of HTS Theological Studies and a research associate of $\mathrm{Dr}$ Andries $\mathrm{G}$ van Aarde, honorary professor at the Faculty of Theology, University of Pretoria.
} 
Palestine, Jordan, and Egypt in the first centuries CE, and before Islam became the religion of the majority in this area.

It is an important point that the map is found in a room, where a Christian congregation of today holds services. It is not a museum and the map is not an exhibited item; the map is still where it was found, and serves as the floor in a church room, and a Bible and liturgy books and other holy things are found in the room. There is probably no direct historical line from the map to the present church, but the presence of the antique map in a modern church is an image of Christianity then and now. Christianity was present in these countries before Islam came into being, and there is a line from then to now. It is not the aim of this paper to reconstruct this line, but just to stress that Christianity in the Arab countries has as long a history as Christianity itself.

\section{PALESTINIAN CHRISTIANITY FROM THE BEGINNING}

This is also true for Palestinian Christianity. If you ask a Palestinian Christian, when her or his family converted to Christianity, thinking that they had been Muslims earlier, the normal answer will be, that they became Christians two thousand years ago. They subscribe to the idea that their forefathers were among the first generation of Christians. Whether this is true for that specific family or not is impossible to prove, but there is a nucleus of truth in the statement. There has always been Christians in the Holy Land, but we don't know the early history in detail. In the congregations were members of mixed origin; there were Jews, who had followed the first apostles' preaching. They were the Judaeo-Christians, but they lost their Jewish identity during the years, when a new Christian identity was developed. Pilgrims from other parts of the world joined these first congregations, and there might also have been Arab members from the beginning. In the years before Islam came to the area, there were cities and villages with a Christian majority. When they accepted the Arab language as their language, in which they also served God, is not certain, but they are the forerunners for the present time's Palestinian Arab Christians.

In the $7^{\text {th }}$ century, Islam came into life and was spread fast over the Arab world, including Palestine. Some Arabs might have been forced to join Islam, but it seems that most of them found that Islam was a more genuine Arab religion than Christianity. However, not all Arabs became Muslims, and Christian congregations were still scattered over the Arab world. Christianity was allowed, because of the Christians have their own Holy Book, and from the $7^{\text {th }}$ to $12^{\text {th }}$ century there are traces of a theological dialogue between the two religions. Furthermore, some of the Christian theologians presented a 
thinking, which deals with Christianity's new problem to be a minority in the Muslim world (Gräbe 1999:107-108).

The dialogue seems to have stopped around the period of the crusades in the $12^{\text {th }}$ and $13^{\text {th }}$ centuries. In the Muslim world the crusades are considered an attempt from the Christian West to press Christian culture upon the Muslims (forcefully and in an imperialistic way) (Maalouf 1983). They still fear a new crusade from the west, and there is no doubt that there are people in the Arab countries, who interpret, what today is going on in Iraq, as a modern crusade.

When you read about the time of the crusades in traditional European history books, you will first and foremost learn a lot about, what happened then in Europe, and about competition between European Kings and Princes. You will also read about the physical and spiritual fight between the Western and the Eastern churches, and finally you get a description of how the wars between Christians and Muslims took place. One thing, however, one looks for almost in vain, is what happened to the local Christians in the Arab countries, and did they have a role to play? An example: In the three volume Church history in Danish, which was the standard textbook, when I was a student of theology in the fifties and sixties, is found very little about the local Christians. The following sentence (in my translation) is almost all one finds about the oriental Christians: "All supporters of the oriental churches were forced to recognise the sovereignty of Rome, which caused a strong indignation" (Holmquist \& Nørregaard 1946:370).

The crusaders did not seem to fight the Muslims, because the Christian outpost in the Holy Land was threatened; they were full of anger, because they themselves did not have access to the Holy Sepulchre, and they were afraid that the Muslims would kneel down there instead of themselves. The aim was to release the tomb of Christ not their fellow Christians.

But the local Christians lived there, also during the two centuries of crusades, and some of the crusaders actually stayed in the Holy Land and mixed with the Arab Christians. This is, for example, the reason why an Italian familyname like Canawati is found in Bethlehem. In the centuries between the crusades and modern days the Christians lived a relatively peaceful life together with their Muslim neighbours. Of course there were restrictions, but not more than it was possible to accept, as long as there was peace in the area. Never has there been an immigration of Arab Christians like the immigration we have seen during the latest decades. The reasons given by the Christian Palestinians, who have left the country in the last fifty years, are first and foremost the political conditions and the lack of employment, and not that they can't live together with the Muslims. Only 3\% of those who have left the West Bank find religious fanaticism the main reason for immigration (The 
Sabeel Survey on Palestinian Christians in the West Bank and Israel 2006:84).

Arab Christians existed as a minority, and therefore they have never developed an imperialistic Christianity like the one, we have seen in Europe and the United States. Most of the Arab Christians are pacifists, and that has also been the attitude of the Palestinian Christians towards the establishment of the modern Israeli state. One cannot deny that Muslims in some of the Arab countries have tried and still try to get rid of Christians especially during the latest decade, but in Palestine that does not seem to have been the case, but the change in the composition of ethnic and religious groups has made the Christians feel a new kind of difficulty.

\section{PALESTINIAN CHRISTIANITY TODAY}

These difficulties have forced some of the Palestinian theologians to rethink their situation and redefine their role as Christians in the Holy Land. There is a new theological movement, which is described in the book by Uwe Gräbe mentioned above. The situation, as the Palestinian Christians were used to it, is defined by one of the theologians in this movement, the Roman Catholic Rafiq Khoury: "I am a Christian, I belong to a minority, I am an Arab, I live an a disrupted church, and am related to the Muslim world" (Gräbe 1996:164, my translation).

Rafiq Khoury mentions that he is Christian, before he calls himself an Arab; probably many of the lay Arab Christians would mention the words in the opposite order. Furthermore, for many of them it is more important that they are Arab Christians, than to which church they belong; but it is a matter of fact that they belong to different churches. For many Christians around the world it is a serious matter, that Jesus' prayer "May they all be one" (Jn 17:21) has never been fulfilled. But in Palestine and Israel this is not a theological problem only, it is also a practical and a political matter. It is difficult for the Christian leaders to convince other leaders in the country to give up all fighting and competition, when they cannot cease to disagree among themselves as Christians.

Nobody knows for sure, how many Christians there are left in the country, and one of reasons is that Christians are leaving all the time. Statistics can be presented in many different ways, and often there is a political purpose behind the differences. But today there are probably around 160000 (The Sabeel Survey 2006:48). Most of the Palestinian Christian families belong to an orthodox church, first and foremost the Greek Orthodox. Among the Catholic Churches the one called the Greek Catholic or the Melkite Church, a Church with an Eastern liturgy in Arab, but in union with Rome, is 
the church with most members. The Roman Catholic Church, or as it is called in this part of the world the Latin Catholic Church, is smaller than the Greek Catholic church, but it is very visible, because most of the modern churches on the places mentioned in the New Testament, to which the tourists and pilgrims travel, belong to this church and are looked after by the Franciscans.

The orthodox churches are the classic churches in the Holy Land, and the history of the Latin Church also goes way back, except for some centuries after the crusades. From the middle of the $19^{\text {th }}$ century, different protestant churches have been part of the Christian family in the Holy Land, especially Anglican and the Lutheran churches. These are small, but very visible, because they have a praxis oriented theology. During the latest decades other churches like the Methodists, Baptists, and Adventists have build churches and established small congregations in the land. Consequently, the Palestinian Christians do not serve God in the same room and in the same way, except on special occasions. They don't take communion together, and it is difficult to recognise them as a union, which would be able to play a role in the present difficult situation; still, many of the Christians are active members of the peace groups.

\section{THE CHRISTIANS AS NEIGHBOURS TO MUSLIMS AND JEWS}

The Christians in the Holy Land have inner fronts, the separation in several churches, but they also have outwards fronts. Rafiq Khoury points to, what has always been the condition for the Palestinian Christians and for that matter for all Christians in the Arab world, namely that they are minorities in the midst of the Muslim world. We cannot expect to find an Arab Christian theology dealing with the contemporary situation, which does not deal with the relation between Christianity and Islam. It is crucial for them that they seriously consider their relation to Islam. This means that we, who are brought up in another part of the world, where Islam is not (yet) an important power, will find themes in their theology, which are foreign to us, and we may even find them irrelevant. In Northern Europe, where the present writer grew up, the fear of Islam is fast growing, and for that reason it is difficult to start a dialogue with the few Muslims, who live here. The Palestinian and other Arab Christians cannot avoid this dialogue, even if it is for them becoming more difficult too.

In the $20^{\text {th }}$ century, the situation has changed a lot for all Palestinians, including the Christians. In the beginning of the century there were less than one hundred thousand Jews in the country and by the end there were some five million. In the same period of time the Muslim population grew from 
around half a million to three million people, in spite of the fact that many Muslims have left the country. Most of them went to other Arab countries, but several of them are scattered around the world. By the end of the $20^{\text {th }}$ century, the Christians were a little more than double the amount they were in the beginning of the century; had they had a natural growth, they would have been more than half a million (The Sabeel Survey 2006:47). In other words the Christians constituted about $10 \%$ of the population in the year 1900 , but less than $2 \%$ in the year 2000, and the main reason for that is immigration, to other Arab countries, to North and South America, and Europe. It should be obvious that this development has placed the Palestinian Christians in a radical new situation, which can hardly be judged as a change for the better.

The founding of the modern state of Israel in 1948 changed the situation, but as a whole the Palestinian Christians accepted this. They had to revise their self-knowledge, both as human beings and in politics and religion. Most of them have chosen to work for, what has been called a prophetic and not a militant solution to the conflict. They had to write and talk and act in order to solve their problems, and consequently very few of the Christians joined their Muslim compatriots in their warlike acts during the periods of intifada, of which the second, which started in September 2000, has not ended yet.

\section{PALESTINIAN CONTEXTUAL THEOLOGY}

It is the theological work, developed by some Palestinian theologians in connection with their self revision, Uwe Gräbe in his book, Kontextuelle Palästinensische Theologie, calls contextual theology. He has made a thorough investigation into the background of this theology and an analysis of how it has developed from the establishing of the Israeli state and until the late nineties, when the book was published. In one of the chapters he presents the most important spokespersons for this theology, and by means of a few catchwords he characterises their special contribution. Geries Sa'ed Khoury, a Greek Catholic or Melkite Christian, has worked with the Arab Christian-Muslim tradition, and Elias Chacour, another Melkite, has presented a narrative theology. Naim Ateek (see below) is an angelical, who himself calls his work liberation theology. Mitri Raheb, who is Lutheran, gives the context the highest priority and Munib A. Younan, another Lutheran, has dealt with Lutheran confession and the dialogue. Then there is the above mentioned Latin Catholic Rafiq Khoury, whose catchwords are the Gospel and the culture, and finally the Latin patriarch Msgr. Michel Sabbah is mentioned - 
he stands for the diplomacy of the Church (Gräbe 1999:154-168). ${ }^{2}$ It is clear that the Catholics, both Greek and Latin, and the Protestants are the most active in the movement; there doesn't seem to be much space for a contextual thinking in Orthodox theology.

The Anglican theologian Naim Ateek (1989:5-6) prefers the designation liberation theology because of its use in emphasizing the liberating aspect of the Word of God. In other parts of the world, where a liberation theology is developed, the exodus myth plays a central role, but the Palestinians don't need an exodus, and the exodus motif has been used by the other part in the conflict, the Israelis. I prefer, in concurrence with Gräbe, to use the term contextual, even if this designation too is used about other and different kinds of theology around the world. A theology is contextual, if it takes up and reflects upon the contemporary situation, in which the theologians in question live, and that is exactly what these Palestinians have done. Some of their thinking is original and unique, because you can hardly find a Christianity anywhere in the world, which is placed in a situation, analogous with the Palestinian situation.

As mentioned above the Arab Christians have for many years lived next to the Muslims as a tolerated minority, and they were used to do so, even if they were depending on the rhythm of the life of the Muslims. During the second half of the $20^{\text {th }}$ century, this has become more difficult, in Palestine especially after the first intifada started in the beginning of the eighties. The more the Muslims have felt the pressure from other people the more dogmatic and militant they became. The less they managed their situation the more the turned to their religion. They have chosen to make the Muslim laws and rules a central matter, and this attitude has been supported from the international Islamism, which has grown up from the beginning of the seventies, wanting a clean and strong Islam. As a kind of answer to this the Palestinian Christians have joined and started associations, where a dialogue between the different parts can take place. In this case it is very important that the contextual theology should be ecumenical. Ateek and Raheb have founded the Sabeel Centre in Jerusalem and the International Centre in Bethlehem. There are also several other centres and associations, old and new, where the dialogue from different viewpoints between Judaism, Christianity, and Islam is encouraged and kept alive.

\footnotetext{
${ }^{2}$ Some of the above mentioned theologians have written books, which are available on the international market. Rafiq Khoury is the editor of the Al-liqa' Journal, and some of the other here mentioned theologians are members of the editorial board. The Journal deals with the Christian-Muslim relations and Palestinian Theology. I have chosen here to concentrate on these contextual theologians, and therefore I don't mention recent literature, dealing with the same topics, written by other Palestinians and authors from the rest of the world.
} 
Another new and may be even more important theological problem is related to the Jews and the modern Israeli state. Throughout the Christian era, there have almost always been Jews in the Holy Land, but they were small groups and an even smaller minority than the Christians; they were never really a political power. Now-a-days the Israelis are the majority in the country, and after the six days' war in 1967, they have dominated not only the Israel they got in 1948, but also the part, which should have been the independent country Palestine.

The Israelis came to the country with a very strong national and in most cases also religious identity; based upon this identity they claimed to have the right to country, and many western Christians supported them, some of them in the extreme form of Christian Zionism (Sizer 2004). They interpret what happened as the fulfilment of the promises from God, known from the Hebrew Bible. Furthermore the Israelis, who came to the country after the second World War had their own or their fellow Jews' experiences of Holocaust, which tied them together and made them eager not to loose the country again. It is fair to say that the Palestinians, who lived in the country and had lived there for centuries, did not have a Palestinian identity, which was anything like the Jewish identity. But during the period around and after the founding of Israel they experienced the loss of country and property, which tied them more, but not fully, together.

It is normal Christian thinking that all Christians are heirs to the Old Testament promises. A central Old Testament theme like election goes through the Old and New Testament and has become a central theme in both Judaism and Christianity, even if there are differences in the interpretation thereof. Thus, also the Palestinian Christians have understood themselves as part of the biblical people of God in continuation of the Old Testament. But the founding of Israel and the return of the Jews has put a question mark against this understanding. Many Christians in the West have, as mentioned above, seen the events happening in modern Israel as a fulfilment of Old Testament promises, and the Christians, who are Palestinians and live in the country, can consequently not represent this fulfilment (Ateek 2005).

Seen from the angle of a special Christian Zionist logic, when looking at the Holy Land, only Jews can represent this fulfilment. The Christian Palestinians don't do that, and therefore they don't belong to the country. The Jews, who have established themselves in a modern state in the country, from where Palestinians also Palestinian Christians have been driven away, are according to that logic the only legitimate heirs of the country (Jeppesen 2007:34-35). In this way the Palestinian Christians are forced into a disagreement with other Christians, especially, when it comes to how to read 
the Bible. They feel that part of the Christian world has used their Bible against them. Therefore some of the Palestinian lay people are developing of kind of neo-marcionism?, rejecting the Old Testament as part of the Bible. The contextual theologians reject that that line of thoughts.

In the case of the right to the country theology and politics are mingled. Many Muslims in Palestine believe that their Christian neighbours are agents for western politics and power. People in the west have difficulties giving the Palestinian Christians the right to live in the country, because of the way they read the Bible. At the same time they suspect that the Arab Christians are spokespersons for the Arab case against the Jews. Very often support to even a small group of Palestinians like the Christians immediately is interpreted as a critique against the state of Israel, if not a new anti-Semitism. Therefore many people, who would like to support the good work done in Palestine for instance by the Christians, find it hard to do so. The problem is that the special logic mentioned above, according to the contextual theologians is a confusion of what is spiritual and what is worldly - and I believe they are right.

\section{JUSTICE WITH MERCY}

I cannot in this short article go into a thorough discussion with all the members of the contextual theology movement in Palestine; I confine myself to referring to Uwe Gräbe's book about this movement. In the present writer's opinion the two books, which give the best introduction to this theology are Naim Ateek's Justice and only Justice and Mitri Raheb's I am a Palestinian Christian. I have earlier introduced the readers of this periodical to the latter, ${ }^{3}$ and therefore I will here concentrate on the first.

Naim Ateek is a typical representative for the group of Christian Palestinians, we are dealing with in this essay; his theology cannot be separated from his own life story. In a section in the first part of his book called A First Experience of Israel (Ateek 1989:7-13), he tells about his childhood. He was born in 1937 in a Christian family in Beisan, which then was a typical Palestinian village with a mixed population of around 6000 people; Muslims and Christians were living next to and in peace with each other. Two days before the proclamation of the Israeli state in 1948, Israeli soldiers came to the village and forced the Muslims to cross the nearby Jordan River and to take flight into the state of Jordan. The Christians were separated from the Muslims and deported to Nazareth, which was supposed to become a village in the Arab part of the country. Later, Nazareth was captured by the Israelis. In this way Naim Ateek came to live as a Christian

\footnotetext{
${ }^{3}$ In a review of Mitri Rahebs book, I am a Palestinian Christian in HTS 58, 2002, 841-844.
} 
Palestinian in Israel. But the family could not move back to or get compensation for their property in Beisan, which now was called by its biblical Hebrew name, Bet Shean, and their house was occupied by Israeli newcomers.

The family found, like many other Palestinian Christians that the Eastern Orthodox Church, to which they originally belonged, had let them down and was too passive. Instead they joined a church, which they found more active, the Episcopal or Anglican church. That is the reason why Naim got an Anglican minister's education and a doctor's degree in the States. Later in life he became a canon at the Anglican St George's Cathedral in Jerusalem, and now he is the leader of the above mentioned centre Sabeel, an ecumenical centre for liberation theology and for justice.

The title of the book in question, Justice and only Justice, is a quotation from Deuteronomy 16:20, and justice is a keyword in Naim Ateek's theology. The Christian God, who is believed to be a saviour and a liberator, seems from the Palestinian Christians' point of view to have revealed himself as partial and discriminating. "How can the Old Testament be the Word of God in light of the Palestinian Christians' experience with its use to support Zionism?" (Ateek 1989:78). A Palestinian Christian cannot in Ateek's opinion accept the Old Testament's understanding of God in full. God's acts in history have to be seen in the light of, what we know about God through Christ; if you don't read in that way, the whole Christian Bible cannot be the Bible for the Palestinian Christians.

One of the keys to the understanding of the Palestinian contextual theology is the way they read the Bible, their exegeses. Therefore, I will end this article by an example of Naim Ateek's exegeses. He reads three Old Testament texts, using the New Testament as a filter (Ateek 1989:86-92). The first section is "Naboth and the God of Justice", in other words 1 Kings 21; the second is "The ecstatic Prophets - A cautious Warning" about Micah ben Jimla, 1 Kings 22, and finally "The Cry of a Refugee - Hope in God" about Psalms 42-43: "As a hind longs for the running streams, so I long for you, my God".

In Ateek's book the biblical texts and their interpretation are not just a proof of what he wants to say or an illustration, but part of the ongoing argumentation. I have chosen the story about Naboth and his vineyard, because this is an example of a biblical story, where it makes good sense to discuss the keyword justice. This story is about a ruler, who twists the law in order to take the land from people, who own it legally. "The death and dispossession of Naboth and his family has been reenacted thousands of times since the creation of the State of Israel" (Ateek 1989:87), and one 
wonders whether some of the people in Palestine today don't enjoy the end of this story: "Exact and strict justice was meted out as punishment for the crime" (Ateek 1989:88).

However, revenge is not part of Naim Ateek's theology. The message is "God's uncompromising concern for justice". The liberation found in the story is, that what is told about Ahab and Jezebel shows that God is a living God with a long memory. (It is typical for this author to explain an Old Testament text with a New Testament quotation. In this case he is referring to Gal 6:7: "God is not to be fooled; everyone reaps what he sows.")

God's right is equal for all; everybody's life and property is under the protection of God. "Whenever injustice occurred, God intervened to defend the poor, the weak, and defenceless" (Ateek 1989:88). But God's punishment without any compromise has to be read through New Testament glasses, and that is very different from the way in which exegetes normally read the Old Testament. But it is not enough to show the historical distance to the idea "eye for eye, tooth for tooth"; you have to reject the whole idea. Instead of "justice without mercy" the Christians, and especially the Palestinian Christians, should argue for "justice with mercy" (Ateek 1989:89).

The contribution of the contextual Palestinian theologians is: don't stop claiming justice, but use the idea of justice in a dynamic and creative way in order to obtain peace in the Holy Land. We should not translate the end of the story about Naboth's vineyard in a literal way, bringing death over every Ahab and Jezebel, but use the story in its totality to awake the hope of liberation for all oppressed.

\section{Works consulted}

Ateek, N 1989. Justice and only justice: A Palestinian theology of liberation. New York: Orbis.

Ateek, N (ed) 2005. Challenging Christian Zionism: Theology, politics and IsraelPalestine conflict. London: Melisende.

Chacour, E 1984. Blood brothers. New York: Flemming H Revell.

Chacour, E 2001. We belong to the land: The story of a Palestinian Israeli who lives for peace and reconciliation. Notre Dame, IN: University of Notre Dame Press.

Gräbe, U 1999. Kontextuelle palästinensiche Theologie, Streitbare und umstrittene Beiträge zum ökumenischen und interreliösen Gespräch.

Missionswissenschaftliche Forschungen, Neue Folge Bd. 9, Erlangen Verlag für Mission und Ökumene.

Holmquist, H \& Nørregaard, J 1946. Kirkehistorie I: Oldtid og Middelalder. Schultz

Forlag, 3rd ed. København: Akademisk Forlag.

Jeppesen, K 2007. Nabots vingård i palæstinensisk udlægning. DTT 70, 23-37. 
Maalouf, A 1983. Les croisades vue par les Arabes. Paris: Jean Claude Lattès (see Danish translation, Korstogene som araberne ser dem, Gyldendals Bogklubber 1997).

Piccirillo, M 1997. The Mosaics of Jordan. Amman: American Center of Oriental Research.

Raheb, M 1995. I am a Palestinian Christian. Minneapolis, MN: Fortress.

Raheb, M 2004. Bethlehem besieged: Stories of hope in times of trouble. Minneapolis, MN: Fortress.

Sizer, S 2004. Christian Zionism: Road-map to Armageddon? Leicester: Inter-Varsity Press.

Younan, M 2003. Witnessing for peace in Jerusalem and the world. Minneapolis, MN: Fortress.

www.hcef.org: the homepage of The Holy Land Ecumenical Foundation a Chronicle (Sept. 23 $3^{\text {rd }}$ 2007)

2006. The Sabeel survey on Palestinian Christians in the West Bank and Israel. Jerusalem: Sabeel Ecumenical Liberation Theology Centre. 